\title{
After Hybridity: Grafting as a Model of Cultural Translation
}

"All translation,” Walter Benjamin states in his essay The Task of the Translator, "is only a somewhat provisional way of coming to terms with the foreignness of languages" (Benjamin 2007 [1921], 75). The notion of cultural translation as it was suggested by postcolonial studies in the past decades stands, as it seems, under the heading of a similar idea, namely coming to terms with the foreignness of 'other cultures.' This is, to mention just one famous example, especially true for Mary Pratt's ethnographic notion of “contact zone,” when she is stressing - quite similar to Benjamin - that contact zones refer to a situation in which the modalities of contact are not yet determined, "where disparate cultures meet, clash, and grapple with each other, often in highly asymmetrical relations of domination and subordination - like colonialism, slavery, or their aftermaths as they are lived out across the globe today" (Pratt 2003 [1992], 4).

Here, a second aspect comes into play, which is not about the fact of foreignness but rather about the need for negotiation: Whenever the contact of different cultures is influenced by the circumstance that one party wishes to sell something to the other - whether this 'something' is merchandise, technology or ideology the situation of cultural contact implies a translational process that adapts and integrates the 'own' to the 'foreign' - different traditions, different life styles, different world views. Peter Burke addresses this point in his book What is Cultural History with regard to Christian missionary attempts. Missionaries often tried to present their message in such a way that it would seem to be in harmony with the local culture. In other words, "they believed Christianity to be translatable." At the same time indigenous individuals and groups in China, Japan, Mexico, and Africa, "who were attracted by particular items of western culture, from the mechanical clock to the art of perspective, have been described as 'translating' them in the sense of adapting them to their own cultures, taking them out of one context and inserting them into another” (Burke 2004, 121-122).

In this paper (see also Wirth 2015), I would like to understand this adapting and inserting with reference to the concept of grafting, and thereby differentiate my approach from others that conceive of cultural translation simply as a process of hybridization. In addition, I would like to contrast adaptation and insertion with two notions that have been highly problematic in the debate concerning transcultural relations: namely assimilation and integration. The term 'assimilation' implies not only that one adapts to foreign ways of life - or that one gets 
forced by others to adapt their way of life; it also implies that the self and the other are to be understood as identifiable, homogeneous entities. This is hinted at in the definition of assimilation offered by Haim Hillel Ben-Sasson in the Encyclopedia Judaica - according to which assimilation is a socio-cultural process

[...] in which the sense and consciousness of association with one national and cultural group changes to identification with another such group, so that the merged individual or group may partially or totally lose its original national identity.

(Ben-Sasson 2007, 605)

Three questions arise from this definition, which are, first of all: What are the implications of "original national identity" when such an identity is determined by a fixed cultural frame-set consisting of one language and specific national traditions?

The second question pertains to the understanding of a "merged individual": to merge means 'to incorporate,' 'to conglomerate,' 'to fuse' - and thus refers to the concept of 'hybridity.' Robert Park pioneered the modern notion of hybridity with his influential essay "Human Migration and the Marginal Man," which began with the premise that: "Every nation, upon examination, turns out to have been a more or less successful melting-pot" (Park 1928, 883). This implies both: fusions at a bodily-sexual level and the mixture of traditions, which Park calls "cultural hybrid" (Park 1928, 891). As already mentioned in the beginning: In postcolonial studies hybridity has become a central concept, in order to negotiate the 'foreignness of the other.' Hereby the main thesis is that the relations between different cultures can be described as cultural contact between bodies, languages, and worldviews of highly different backgrounds, whose mixture generates something new, something 'third' (see Bachmann-Medick 2006, 200). The classical terms for describing this dynamics of fusion are, as García Canclini points out in his book Culturas Hibridas: creolization, synchretism, mestizaje. These fusion dynamics are personified by Malinche, the indigenous translator of the Spanish conqueror Cortés, who bore Cortés' child to become the primordial mother of the so-called 'mestizos.' To this day she is a highly controversial figure - and of course, the term 'mestizo' is very problematic, too (see García Canclini 2005, xxxii). What seems interesting about Malinche, however, is that she became an allegory of all the interferences of bodily and conceptual aspects that cultural contacts carry with them. One could even see her as a protagonist in a constellation that Homi Bhabha calls colonial mimicry (see Bhabha 1994, 75-76): a notion that refers to situations in which the colonized appropriate the mixing of their own culture with that of the colonizer as a subversive strategy. Here, of course, 'mixing' stands for the mere pretense of assimilation.

This brings a third question to the fore, which proceeds from these considerations; it has to do with the relationship between assimilation and translation: To what extent do translation processes presuppose a 'making similar,' an imitation, an assimilation of the foreign language into one's own language? A question that 
extends beyond purely linguistic problems of translation, and touches upon what Homi Bhabha is referring to as cultural translation, basing his considerations on Walter Benjamin's essay “The Task of the Translator.” Bhabha understands cultural translation as a process in which we can no longer assume that there is something like an original self with a static identity.

In that sense there is no 'in itself' and 'for itself' within cultures, because they are always subject to intrinsic forms of translation. This theory of culture is close to a theory of language, as part of a process of translations - using that word [...] not in a strict linguistic sense of translation [...], but as a motif or trope as Benjamin suggests for the activity of displacement within the linguistic sign.

(Bhabha 1990, 210)

According to Bhabha's reading, translation becomes a "way of imitating [...] an original" (Bhabha 1990, 210), in which the predominance of the original dissolves through the possibility of being copied and transformed, and thereby reveals a notion of an original "that is never finished or complete in itself. The 'originary' is always open to translation" (210). This implies a concept of the 'original' that does not appear as a homogeneous, static unit, but rather as something unfinished, as something still in motion. Such a conception of a constructed, non-homogeneous, not-yet-complete original impacts the understanding of both assimilation and cultural translation: The original is no longer considered an unchangeable archetype around which processes of adjustment and translation orient themselves; instead, the original itself becomes an object that changes during the translation process - an original in progress. Or maybe even: an original in motion.

The idea that the original itself undergoes change during the translation process, that it leads a life of its own and is not oriented around the principle of equivalence or fidelity, falls in line with Benjamin's thoughts on the task of translation, namely that

no translation would be possible if in its ultimate essence it strove for likeness to the original. For in its afterlife - which could not be called that if it were not a transformation and a renewal of something living - the original undergoes change. （Benjamin 2007 [1921], 73)

With this passage, Benjamin clearly rejects the idea of an assimilating attempt to achieve similarity between a translation and its original. Instead, the translation is described as a living process, which is capable of changing the original in the course of translation. Within this context, the question emerges how such a concept of translation can be applied to the different definitions of hybridity described above. Doing so leads to a striking realization: namely, the extent to which the historical semantics of translation theories has been based on biological and organological metaphors. Above all, we find the image of 'transplanting' languages, which we also see in Benjamin's work when he writes, “thus 
translation, ironically, transplants the original into a more definitive linguistic realm since it can no longer be displaced by a secondary rendering” (Benjamin 1991 [1921], 75). Apparently (and ironically) Benjamin joins here a tradition in the history of translation theory that sees transplantational displacements and relocation as a form of translation: a tradition that engages in cultural translation.

In the following I would like to attempt to illustrate the implications of this engagement as it pertains to the concepts of assimilation and integration. In doing so, I will also show why the concept of 'hybridity' alone is not sufficient to do justice to the complexity inherent in processes of cultural translation. Indeed, my thesis is that we need a second concept as well, namely that of 'grafting' (see Wirth 2011a, 2014, 2017).

\section{1 'Hybridity Model' and 'Grafting Model' in the Sphere of Translation}

At this point I should make plausible, why I think the concept of grafting is relevant for addressing problems of translation, before I will go into some details about the actual notion of grafting.

In his treatise On the Different Methods of Translation Friedrich Schleiermacher compares the task of translation to an exotic, agricultural intervention when he writes that the "diverse transplantation of foreign plants have made our soil richer and more fertile” (Schleiermacher 1973 [1813], 69, my translation). The decisive question is, of course, what actually happens in this translational transplantation. Schleiermacher described the method of translation as a "composure of language that is not grown freely, but is rather bent over towards a foreign similarity" (Schleiermacher 1973 [1813], 55, my translation). What is that supposed to mean? Apparently Schleiermacher refers to a form of translation that attempts, as accurately as possible, to "match the phrases of the original writing," thus giving the reader the feeling that "they have something foreign in front of them" (Schleiermacher 1973 [1813], 54, my translation). Schleiermacher's theory thus represents an example of what has been called an 'alienating translation.' Anne Bohnenkamp - drawing from Mikhail Bakhtin - has suggested that this kind of translation should be classified as a "phenotypically hybrid translation" that seeks

to mix elements of the original text and the original language in such a way that the mixture remains recognizably a mixture - that is, demonstrates the heterogeneity of parts. The antithesis naturalizing [einbürgernd] - alienating [verfremdend] would thereby be replaced by a model that makes not only the differences, but also the similarities of different translation processes obvious.

(Bohnenkamp 2004, 20, my translation) 
The point of this reformulation affects the linguistic surface of the translation, because it is obvious that from a genotypic perspective, translations are always 'hybrid.' Here, the reference to Bakhtin comes into play, who analyses the interdependence between "hybrid culture and hybrid literary forms" (Bakhtin 2002, 63) in relation to operations of "translation," "reworking," and "re-conceptualizing" (Bakhtin 2002, 377-378). According to Bakhtin, languages change historically primarily by hybridization, "by means of a mixing of various 'languages' co-existing within the boundaries of a single dialect, a single national language, a single branch" (Bakhtin 2002, 358-359). In contrast to the non-intentional form of an, as Bakhtin calls it, "historical, organic, obscure language hybrid" (Bakhtin 2002, 360), the artistic hybrid does not function as a mere melting pot, but rather as an arena, where different points of view on the world collide: These two points of view are not mixed, but "set against each other dialogically" (Bakhtin 2002, 360). For Bakhtin, this becomes particularly obvious in parodistic novels, where we find intentional hybrids as "hybrid compounded of two orders," for instance two contradictory styles ("low" and "high"). In these cases, Bakhtin states, "two 'languages' (both intra-lingual) come together and to a certain extend are crossed with each other" (Bakhtin 2002, 75). In my view this is not only true for parody but also for translation: Translation is a process, where different styles of thinking, different ways of speaking, different points of view on the world collide.

This ambivalent aspect of linguistic and cultural hybrids is also an issue in Schleiermacher's essay, when he writes: "who would not rather have children that represent the fatherly lineage purely, rather than as Blendling?" (Schleiermacher 1973 [1813], 54, my translation). With the term "Blendling” Schleiermacher explicitly introduces the concept of hybridity into his theory of translation - but also a curious discourse of purity (see Latour 1993, 59-60). With reference to the Greek expression hibrida, Grimm's Dictionary defines a Blendling as a, "bastard and hermaphrodite in whom the pure, natural type is blurred and mixed, from humans, animals, and plants” (Grimm 1854, my translation). Interestingly, Schleiermacher shifts to another metaphorical register as soon as the "strange similarities" between two languages are overlaid by the cultural differences between worldviews, and the question of contamination is overshadowed by the question of how to make foreign styles of thought compatible. In Hermeneutics and Criticism, Schleiermacher states that the "Christian spirit" in the New Testament "emerges from a mixture of languages in which Hebrew is the root within which the new is originally conceived, while the Greek is grafted on to it [das Griechische aber aufgepfropft]" (Schleiermacher 1977 [1838], 90, my translation).

Apparently, the agricultural technique of grafting - as a form of 'transplantation' - is used as a metaphor in which 'transfer' into a new syntactic context becomes a conceptual and linguistic ‘translation' into a different cultural context. 
At the same time, grafting becomes literally a model for the adaptation processes of foreign elements - be it language, be it thoughts, be it bodies - in which the 'self' and the 'foreign' become connected, but do not mix. In grafted compounds foreign elements get naturalized but not completely assimilated, since they remain visible as foreign elements. At the same time, we can also read Schleiermacher's two-sided description of translation as an indication that recourse to a model of hybridity alone is not sufficient. Indeed, the situation surrounding translation seems to be characterized by the interferences and interactions between a model of grafting and a model of hybridity.

\section{Agricultural Implications of 'Grafting Model' and 'Hybrid Model'}

At this point it is time to explain the notion of grafting in contrast to the notion of hybridity: Together with selective breeding, hybridizing and grafting can be conceived as fundamental techniques of culture (see Siegert 2011). While selective breeding is the purposeful strengthening and weakening of specific genetic traits within a biological species, hybridization is the mixing of different species. The crucial point of hybridization is the genetic mixing of heterogeneous elements. This is how the mule is generated by horse and donkey, as well as how new breeds of fruit trees spring from successful crossings. In contrast to hybridization, grafting does not result in a genetic mixture. It is not a blending, but a binding of two different parts into one organic unit: a combination in a literal sense, whereby the bound parts remain genetically different, and that also means each compound "maintains its own genetic identity" (Mudge 2009, 440), even when they are grown together. While hybridization follows the logic of sexual reproduction (and hence, the logic of sexual contact), namely: a third is made from two, grafting boils down to the idea: make two into one.

A look at a special issue of the Time-Life Encyclopaedia of Gardening on Pruning and Grafting, makes clear what the formula means:

In essence, grafting involves the wounding of two growths and the arranging of them so that they heal together. One of the two growths is called the stock, understock or rootstock. It is the host plant, rooted in the soil and providing nourishment for the other growth, the dependent top section, which is called the scion.

(Allen 1978, 60)

The graft is described as a "friendly parasite" (Serres 2008, 65) that grows with its host. This requires an accurate cut - with the help of special tools - that allows the injured cambium of the rootstock to come into direct contact with the 
injured cambium of the grafted scion. Both parts are subsequently united and adhered with tree wax. Thus, grafting proves to not only be a botanical bricolage that unites foreign bodies in processes of cut and paste; it also proves to be a concept that pertains to a cultural technique of intervention in which the natural circulation of plants juices is not cut off but rather 'rechanneled.' At the same time grafting - like cloning - is a technique of copying, which aims to maintain the purity of a species: hundreds of scions of the same sort (perhaps even twigs from the same tree) are grafted onto suitable roots. The result is a fragile entity of heterogeneous, artificially joined, non-assimilated parts that are still organically integrated with one another. Still, such grafting requires a minimal level of 'compatibility,' which is referred to in biological terms as "vegetative affinity" (see Hertwig 1923, 505).

Particularly in the eighteenth century, grafting also gained a biopolitical relevance (see Foucault 2004, 70): It became an economic figure of amplification, stressing the possibilities of maximization of natural powers, namely the qualitative and quantitative maximization of output. This is what we read in Zedler's Encyclopedia:

Tree grafting is also called impffen, pelzen, and zweigen, and in gardening refers to the work through which a wild and infertile tree-trunk is combined with another that is set upon it, and which is improved by the broken branch of a fertile tree or the so-called graft scion. This is a glorious invention through which wild trees are tamed, the infertile are made fertile and prolific [...], indeed even the color and taste of these trees is transformed and changed.

(Zedler 1961 [1753], 762, my translation)

Although most of these claims are - biologically speaking - false, they express a biopolitical ideology: by combining different parts, by creating a new element, the forces of nature are simultaneously deployed, enforced and controlled. Thus, around 1800, the making fertile, transformation, change and improvement of nature become codes for an attitude in which the cultural technique of grafting appears as a kind of governing technique. This is made especially clear in the encyclopedia of Diderot and D'Alembert. Under the lemma "Greffe," grafting is called the "triomphe de l'art sur la nature” (D’Alembert 1757, 921), because this process enables one to force nature into producing new kinds of plants. This means that nature is modelled on culture understood as practice. ${ }^{1}$ Grafting is

1 This also applies to hybridization, as long as this term is used to refer to crossbreeding initiated by human intervention. The best example to illustrate hybridization in this sense is the mule. Although a mule can result from an 'evolutionary coincidence,' its artificial crossbreeding is determined by an economic motive: A mule is more robust than a horse but less stubborn than a donkey. This controlled procreation implies a biopolitical concept in which hybridization 


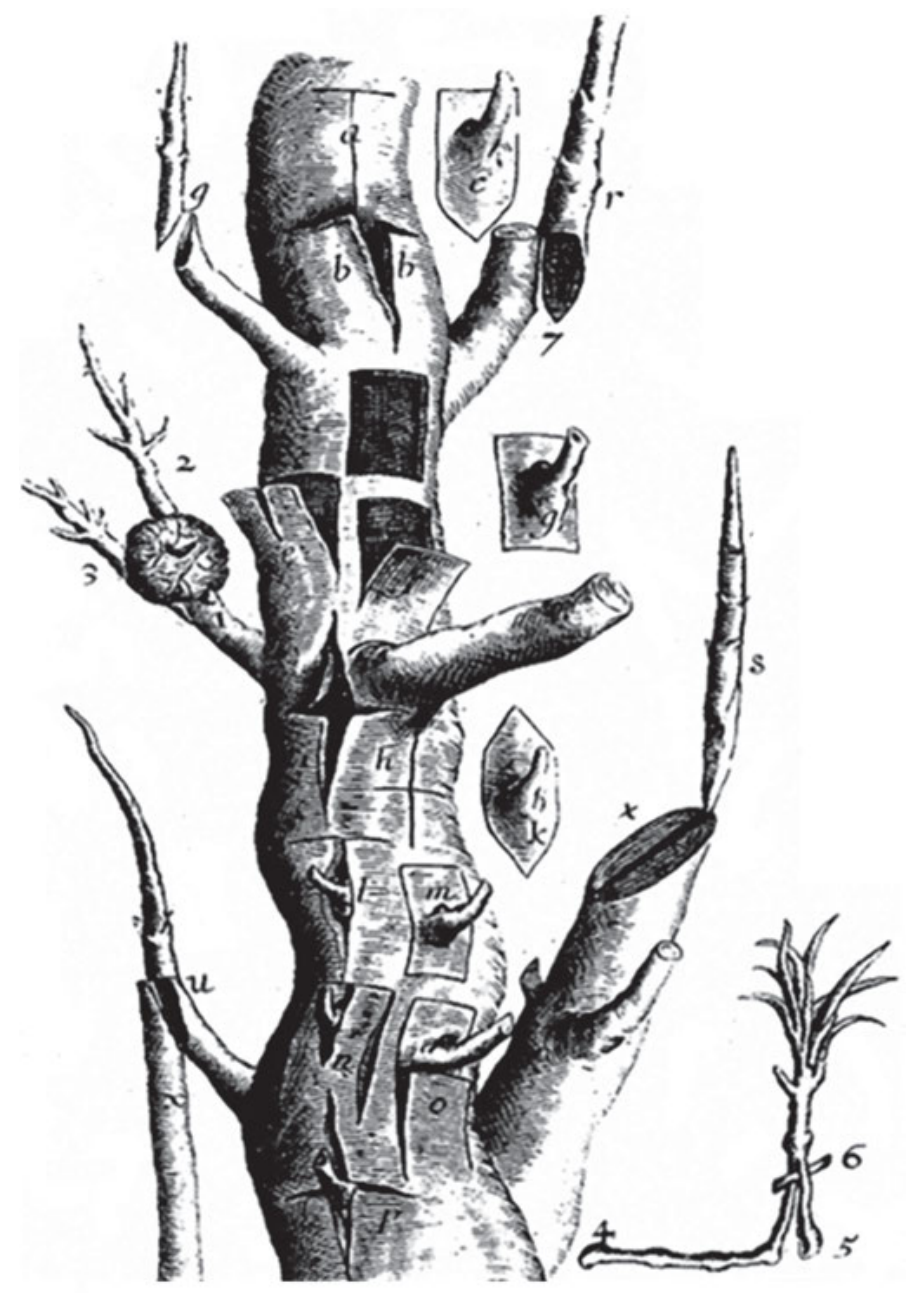

Fig. 1: Robert Sharrock, various methods of grafting, in: The History of the Propagation \& Improvement of Vegetables by the Concurrence of Art and Nature, 1659, p. 59.

becomes what Foucault calls a dispositif [device] (Foucault 2004, 70). What is at stake here are natural resources that can be controlled and even improved by grafting or hybridization with the aim of economic exploitation. This is also the way to overcome the nature/culture split: The total, or even totalitarian economic framing of everything we refer to as nature puts nature at our disposal and into a 'stand-by mode' - what Martin Heidegger referred to as "Bereitstellung" [state of preparedness] (Heidegger 1967, 16). This stand-by mode is the very basis of what is called biopower (Foucault 1984, 257; Bertilsson 2003, 120). 
herewith ascribed the potential to transform primordial plant species into something new, and to transform by means of bringing one species into contact with a foreign graft scion: refinement and cultivation through 'contact' with other plant cultures. At the same time - and until today - one can observe another tendency, namely the metaphorical employment of the agricultural technique of grafting to describe the symbolic cultural technique of 'writing' (see Böhme 1999). Since the eighteenth century one finds 'grafting' used within the framework of poetological discourses as a metaphor for practices of quoting, copying, and commenting. ${ }^{2}$

Indeed, in French, the term greffer signifies not only grafting in the sense of botany and surgical transplantation; the graft is also the concept for an agency of transcription. The "greffier" is, as we learn in the Encyclopédie, a notary scrivener who copies pieces of writing, registers, and archives (D’Alembert 1757, 924).

The German Romantic author Jean Paul even wrote an entire novel about grafting as a plagiarizing, collage-like process of text production: Leben Fibels (1811). The novel depicts the life of a certain Gotthelf Fibel who presents himself as a gifted literary writer even though he actually works as a writer in the literal sense: His passion is copying the Alphabet. Through a series of coincidences, he surprisingly succeeds in becoming famous as the author of an ABC primer (in German commonly called $A B C$-Fibel). As a consequence of his fame, a 40-volume biography (written by some of his employees) is published. Within the turmoil of the Napoleonic Wars, however, the pages of this biography disperse, and only fragments of the original remain - becoming part of every-day life and serving for various purposes such as wrapping paper or spice bags.

The premise of the story is that the editor-narrator Jean Paul attempts to gather and glue together these "fliegende Blätter" as "flying pages" or "loose leaves." The result is a fictional cut and paste in which the titles of the individual chapters announce the location where the fragments are found. In the " 20 th or Pelz chapter," we read:

This entire chapter was found in the grass of an Impf- or Pelz-garden and seems to have been used to bind Pelz wounds, which the reader could interpret as subtly allegorical if he so desired.

(Jean Paul [1811], 464)

Since "pelzen" is (as we saw in the Zedler-Article) an old-fashioned German synonym for 'grafting,' the model of grafting evoked here becomes an allegory for a poetics that draws the lines between original and copied writing. And there

2 See, for instance, Shaftesbury, who describes in his Characteristicks of Men, Manners, Opinions, Times authors who do nothing other than to write commentary in the following way: "They have no original Character [...]; but wait for something that may be call'd a Work, in order to graft upon it [...] at second hand" (Shaftesbury 1711, 269). 
is more: An expert in print by the name of Master Pelz shows Fibel how one can imprint one's own name on the title pages of anonymous works. Thus, the Pelzing as an act of engrafted insertion becomes a gesture of appropriation as well. With this idea Jean Paul gives somehow advance notice to a concept that Jacques Derrida will call greffe citationelle. In his influential essay "Signature Event Context", Derrida introduces grafting as a metaphor for the "essential iterability" of all sign. Due to its iterability,

a written syntagma can always be detached from the chain in which it is inserted or given without causing it to lose all possibility of functioning, if not all possibility of 'communicating,' precisely. One can perhaps come to recognize other possibilities by inscribing it or grafting it onto other chains.

(Derrida 1988, 9)

Here, grafting represents the possibility of a 'force of rupture' with external (historical, spatial, social) contexts, but also internal, linguistic-syntagmatic contexts. And in this sense, as Jonathan Culler puts it, "the graft is the very figure of intervention" (Culler 2007, 141).

Whilst John Austin's speech-act theory is based on the assumption that the process of citation results in a loss of "illocutionary force" in what is said and that citation is a "parasitic" form of language use (Austin 1975, 21), Derrida's conception turns grafting as a citational graft [greffe citationnelle] into a figure that fosters the circulation of communicative power through an act of removing and re-inscribing signifying bodies, that is: through an act of displacement. At the same time one has to admit: re-inscribing or re-inserting signs into other contexts is an ambivalent gesture. Especially with the act of re-integration, the differences between graft and rootstock are marked: The new entity emerges from heterogeneous, artificially combined, unassimilated parts that are forced together.

\section{Implications for a Notion of Cultural Translation}

Here, two aspects of the grafting model are of significant relevance for cultural studies: on the one hand the role of grafting as a figure for describing ambivalent cultural integration and translation processes, in which the foreignness and difference of the translated remain visible; on the other hand the role of grafting as a figure of describing political constellations marked by nonsymmetrical power-relations. It is in this latter sense that Max Weber speaks of "grafted social orders" (Weber 1988 [1918], 516) and describes the relationship between European and Chinese culture as a merely extrinsic grafting of foreign mentalities (see Weber 1986 [1920], 440). Hence, grafting turns out to be a dominant gesture of the Western civilizing mission, since it contains "in germ the idea of transplanting the 
European spirit” onto the traditions of other cultures (Acheraïou 2008, 33). Robert Young followed a similar line of thought in his book Colonial Desire: Hybridity in Theory, Culture and Race, in which he traces the political, and most centrally the terminological politics, of using organic metaphors to describe social forms of organization. The concepts of hybridity and grafting stand at the center of interest, because both terms denote the phenomenon "of forcing incompatible entities to grow together (or not)" (Young 1995, 4).

Maybe it is time to pursue a research project that analyses all the metaphorological (sensu Blumenberg) implications that models of hybridity and models of grafting bear (working-title could be: Graftology). The aim should be to develop a notion of cultural translation that is taking into account all the interactions and interferences between the 'hybridity-model' and 'grafting-model' - such as for instance the dynamics of forcing incompatible entities together, or the process of negotiating the modalities of how these entities come into contact. The argument could be this: As we saw in the initially quoted passage by Bhabha, the term 'translation' became a trope for the "activity of displacement within the linguistic sign” (Bhabha 1990, 210). The term 'displacement' obviously signifies two things in this context: First, similar to the way it is employed by Derrida, it refers to the internal sign structure of statements and is then projected onto the external dynamics of sign usage. Second, 'displacement' stands for a political dynamic of 'rupture' in which people are torn from their 'original' home contexts and forced to migrate to new contexts, 'foreign' to them.

In my view, such an interpretation of the concept of cultural translation displays the same dynamic as that which Derrida calls greffe citationelle: The displacing 'rupture with context' and the grafted insertion into another context finds its re-entry here in form of a greffe culturelle.

At the same time some of the precarious political implications that the grafting model carries with it become visible: It carries traces of the state of being torn out and placed as a mark of cultural difference onto another, foreign context; and it becomes herewith a model not only for justifying the possibility of integrating signs and people, but also for mobilizing forces that repel migrants as 'foreigners.' Maybe one could say that grafting is a parasitic model of what Pratt calls "contact zone," where disparate cultures "meet," often in "highly asymmetrical relations of domination and subordination - like colonialism” (Pratt 2003 [1992], 4). Indeed, the model of grafting also implies a specific form of cultural dominance: in the context of colonial constellations, it gives expression to a superior position of power. It relegates the colonized to the role of a wild substratum that can be cultivated by quasi-horticultural interventions. The hybridity model, on the contrary, encounters this play of power with a semantics of subversion, through which an interference between the logic of grafting and the counter-logic of hybridity emerges. 
In consequence, a relationship of strained interference between a logic of hybridity and a logic of grafting arises. This interference is indicative of a highly complex situation similar to the situation Bruno Latour describes in his book We Never Have Been Modern. According to Latour, the project of modernity is initiated by an ambiguous dynamic; the word 'modern' designates, as he points out, two entirely different sets of practices:

The first set of practices, by 'translation,' creates mixtures between entirely new types of beings, hybrids of nature and culture. The second, by 'purification,' creates two entirely distinct ontological zones: as for instance that of human beings on the one hand; that of nonhumans on the other.

(Latour 1993, 10-11)

While the "modern critical stance" (Latour 1993, 11) always tried to keep these two sets of practices separate, the pre- and postmodern styles of thinking have confused the practices of translation and purification. I would like to argue that this confusion can also be understood as a certain kind of interference between 'hybridity-model' and 'grafting-model.' Since in grafting the combined genetic elements are not altered, it is an operation to produce a 'pure copy' - the concept of combining different bodies is connected to an emphasis on the genetic difference of the elements. Hence, grafting stands for a strategy of purification. In hybridization, on the other hand, the genetic differences are overridden by 'crossing' and 'translation.' But the most interesting aspect is, I would like to suggest, the style of confusion between 'hybridity-model' and 'grafting-model.'

In Homer's Iliad we find a famous description of a hybrid called chimera: Its front part is that of a lion, the back is that of a dragon and in the middle it is a goat. In a chimera, apparently, the style of confusion between logic of grafting and logic of hybridization is significant: The connected parts are not represented as mixed together, but as placed together: a phantasmagorical cut and paste. To put it in another way: Maybe fairytale creatures, monsters like chimeras or centaurs, are figurations of hybridity represented in the representational mode of grafting. Today, we have become aware again of such phantasmagorical and monstrous creatures (see Paré 1841, 23), which raise the question of the borders and limits of the human body in the context of biopolitical ideologies. For instance, we have representations of a chimera-like combination of human and machine - think of the movie Robocop (1987) - and maybe our high-tech culture is a culture in which the hybridization of machines and organisms is becoming a normality. Taking into consideration the various possibilities of using prostheses or of transplantation medicine (see Hamilton et al. 2012), we find ourselves, as Donna Haraway stated in her "Cyborg Manifesto," "to be cyborgs, hybrids, mosaics, chimeras" (Haraway 1991, 177). 
In fact, the various modes and styles of confusing grafting-model with hybridity-model are quite puzzling, since it is by no means clear why and when they occur - maybe they indicate situations similar to what Hans Blumenberg called "Logical Embarrassment" [Logische Verlegenheit] (Blumenberg, 2005 [1960], 10). It is very often literature that becomes the playground where the consequences of these logical embarrassing confusions between grafting and hybridity are represented and negotiated. Just to mention one example, well known in postcolonial studies: In Salman Rushdie's The Satanic Verses (1988), the relation between graft and hybrid is re-negotiated in a very obvious way. It is not only that the "genetic possibility of centaurs was being seriously discussed" (Rushdie 1988, 467); on another occasion we even find the confusion of graft and hybrid as a keyword. One of the protagonists, Otto Cone, a Polish Jew who immigrated to England after he survived Nazi-Concentration Camps, tries to assimilate to his new home-land: not only by changing the family name from Cohen to Cone, but also by starting to adapt to one of the most popular hobbies in England: gardening. Rushdie chooses to let a tree become the symbol of Otto's wish to assimilate in an "incompatible world" (Rushdie 1988, 471):

After Otto's death Alicja [...] planted vegetables in what Otto had insisted should be an English floral garden (neat flowerbeds around the central, symbolic tree, a 'chimeran graft' of laburnum and broom).

(Rushdie 1988, 476)

Apparently, for Rushdie the "chimeran graft" also becomes a metaphor for the paradoxes and logical embarrassments of cultural translation. The crossing of laburnum and broom implies a special kind of cultural contact taking place 'in-between' the logics of graft and hybrid. At the same time, it transposes and translates two central horticultural - and biological - questions of the nineteenth century into twentieth century discourse about assimilation, integration, and intercultural contact.

When Charles Darwin was dealing with the problem of explaining the physiological processes involved in heredity and reproduction in his book The Variation of Animals and Plants under Domestication (1886), he chose the Laburnum Adamii as an example of the rather puzzling phenomenon of transition: "Mr. Adam inserted in the usual manner a shield of the bark of $C$. purpureus into a stock of C. laburnum; and the bud lay dormant, as often happens, for a year" (Darwin, 1886, 390). In other words, Adam practiced a certain technique of grafting, called oculation.

If we admit as true Mr. Adam's account, we must admit the extraordinary fact that two distinct species can unite by their cellular tissue, and subsequently produce a plant bearing leaves and sterile flowers intermediate in character between the scion and stock, and 
producing buds liable to reversion; in short, resembling in every important respect a hybrid formed in the ordinary way by seminal reproduction. Such plants, if really thus formed, might be called graft-hybrids.

(Darwin 1886, 390)

For Darwin, graft-hybrids point to an extraordinary fact. Between grafts and hybrids there are intermediary forms: figures not only of transition, but of what I suggest can be called translation, to which both the formulas two into one and two into three apply. In Rushdie's text, the graft-chimera (a term that in biology is still used synonymously with graft-hybrid) becomes a model for the connection of multiple parts of different origin. It not only stands for the "body eclectic" in an "incompatible world" (Rushdie 1988, 647), but also represents the condition of an all-encompassing 'in-betweenness.' In both cases - Darwin and Rushdie - the graft-hybrid functions as the ambiguous figuration of a classificatory undecidability. It incorporates and embodies the condition of 'in-between,' being subject exclusively neither to a logic of grafting nor to a logic of hybridization. This condition questions the plausibility of the dichotomy of grafting and hybridization and, at the same time, marks an ambiguous situation that configures not only the split between nature and culture but also the gap between one culture and another.

\section{Cultural Translation}

Against the backdrop of what was said so far, I would like to come back to Schleiermacher and pose the question what it means when he describes the act of translation as a "transplantation of foreign plants" that "have made our soil richer and more fertile" (Schleiermacher 1973 [1813], 69). In my view it is noteworthy that Schleiermacher did not introduce this motif of reciprocal influence between foreign plants and native ground in the sense of a concept of terroire in which the ground influences the plant through the roots. Instead, his conception is reversed: The ground is influenced by the plant. This is an opposing model to the concept of originality made prominent by the European genius-aesthetic as proposed by Edward Young. In his 1759 work Conjectures on Original Composition, Young makes the assumption that the original is rooted in the fertile ground of a natural genius: "an Original may be said to be of a vegetable nature; it rises spontaneously from the vital root of Genius" (Young 1759, 12). In contrast, the imitator appears as a, "transplanter of Laurels, which sometimes die on removal, always languish in a foreign soil” (Young 1759, 10). In other words: The process of copying and imitation is described here as transplantation to new ground, which leads the transplanted plant to become weaker. 
There is a third possibility to reformulate the problematic relationship between assimilation and transplantation, namely with recourse to a concept of originality that uses botanical metaphors without paying homage to the idea of a homogeneous primitive nature as found in Young's writings. Such a concept can be found in Herder's Fragments on Recent German Literature (1768), where he first writes, following Young, that, "every book is a bed of flowers and growths; every language an immeasurable garden of plants and trees" (Herder 1985 [1868], 552, my translation). Shortly after this, however, Herder provides a totally different kind of linguistically critical summary when he - in contrast to Schleiermacher strikes rather xenophobic tones while remaining in the garden paradigm:

Which revolutions did the German language undergo, partially within its own nature and partially through the admixture of foreign languages and ways of thinking in order to change its mind while its body remained the same? How full is the language taught in foreign colonies [fremde Kolonien], which have taken on German dress, German civil rights, and German habits? How many foreign branches have been grafted onto the tree-trunk of our literature - how they are on the trunk where it is not degenerated, but rather changed and often refined?

(Herder 1985 [1868], 567, my translation)

The question is, of course, what Herder meant when he used the term 'foreign colonies.' I would like to suggest that this expression is referring to the so-called Antiqua-Fraktur-dispute. In my view it is an allusion to the typographical convention of printing all foreign words in Antiqua, while the German text was printed in Fraktur. According to this convention, the difference between Antiqua and Fraktur becomes a cipher for ostentatious non-assimilation: Foreign words remain foreign within a field of native Fraktur script (see Wehde 2000, 216). At the same time, foreign words also represent an externalized 'foreign similarity' that forms the basis of Schleiermacher's concept of an alienating translation.

But if foreign words are 'colonies' that are marked as 'foreign words' by a different typographical form (Antiqua), then don't the German words written in Fraktur take on the systematic position of an indigenous people? And when Herder claims that foreign colonies have taken on "German dress, German citizenship, and German customs," then the formulation "German citizenship" obviously plays with the possibility of a naturalizing form of translation. The naturalization of a foreign word, the translational adoption of a 'foreign similarity,' appears here as a form of colonial mimicry within the framework of written culture: on the one hand, an assimilation of the typographical dress-code; on the other hand, a linguistic assimilation of foreign words with regards to 'German grammar.' In this respect, Herder's metaphorical reference to foreign colonies points to the sensitive political problem of linguistic incorporation that remarkably parallels the so-called 'integration debate' seen in Germany today. 


\section{5}

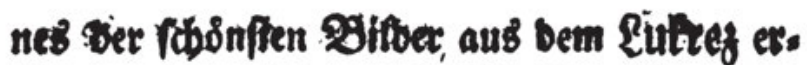 fabren, a fein foeites Bud anfángt:}

Suaue mari magno' turbantibus aequora ventis

E terra magnum alterius fpeetare laborem -.

Suaue etiam belli certamina magna tueri

Per campos inftrueta tua fine parte pericli :

Sed nil dukcius eft, bene quam munita tenere

Edita doctrima fápientuin rempla ferena

Difpicere vnde queas alios, paffinque videre

Errare', atque viam palantes quaerere vitae

Certare ingenio, contendere nobilitate

Nocts's atque dies niti praeftante labore

And fummas entergere opes, rerumque potirl. - -

\section{Wher Daju gebauet iff, um bie Sמoinbeit,} nịt) biefer Beforreibung, fonbern biefes In: bliç zu füblen; bem wirb mein erffes frag: ment Selegenbeit geben, iber feinen. Inbalt filbft mebr madzubenten.

Fig. 2: Page from Herder's Fragmenten über die neueste deutsche Literatur (1768) (Third Collection).

What I find most remarkable about Herder's writing, though, is that despite the somewhat lachrymose tone with which he first characterizes the German language as an entity that has been grafted together, he also recognizes that the "original, peculiar" nature of the national language is a result of exactly this historical grafting: a language that, as he puts it, "is as it is, after its branches have been trimmed and transplanted, with all of its grafted foreign twigs, but still standing as a self-grown tree-trunk, injured but not dismembered by bare hands" (Herder 1985 [1768], 571, my translation). To the extent that around 1800 (but also for the remainder of the nineteenth century) language as 'national language' constituted the definitive point of reference for what was described above as "original 
national identity" (Ben-Sasson 2007, 605), Herder describes in this passage a conception of national language in which originality and grafted-togetherness interfere with one another. The national language that has been grown on native soil proves to be a pieced together entity, namely a grafted together language tree that is remarkably unstable and incomplete - and remains, "never finished or complete in itself" (Bhabha 1990, 210). National language, thus, appears to be an 'original in motion' that becomes 'an original' as soon as it is grafted together with linguistic branches from other cultures.

\section{Conclusion}

I would like to conclude by claiming that grafting should be considered to be an indispensible component of any model of culture in which national identity and originality are no longer considered to be paradigms of homogeneous purity, but rather as always unfinished modes of being assembled. This 'being assembled' is, as I tried to make plausible, to be understood not only as a hybrid mixture but also as a grafted combination. This also implies a new conceptualization of 'cultural translation,' which stands at a point of tension between hybridity and grafting. This has two consequences:

Firstly, grafting is a model for the process of cultural translation in the sense of the transplantation of branches of language.

Secondly, the grafted tree becomes a model for an original in motion.

This view gets support from a rather unexpected side: In his book Word and Object, the analytical philosopher Willard Van Orman Quine raised the question of how processes of understanding can be conceived of as processes of translation. In trying to answer this question, he draws from an eminently botanical register in the beginning of his investigation, when he writes:

Different persons growing up in the same language are like different bushes trimmed and trained to take the shape of identical elephants. The anatomical details of twigs and branches will fulfill the elephantine form differently from bush to bush, but the overall outward results are alike.

(Quine 1960, 7)

What is quite surprising in this context is the strange interference between a natural rootedness of language on the one hand, and its cultural formation via gardening interventions on the other hand. It seems that Quine introduces a ruthless French gardener who trims the flora until it can be used for the presentation of fauna (a colonial fauna, by the way).

There is a second passage in which a botanical register is employed; a passage in which the problem of cultural translation is explicitly addressed - more spe- 
cifically, it addresses a situation of cultural contact in which one does not understand the language of the other at all. In order to assign meaning to words of a foreign, unknown language, we need, as Quine calls it, a "radical interpretation" that begins with the positing of analytical hypotheses about possible meanings:

The method of analytical hypotheses is a way of catapulting oneself into the jungle language by the momentum of the home language. It is a way of grafting exotic shoots on to the old familiar bush [...] until only the exotic meets the eye.

(Quine 1960, 69)

I wonder, how this metaphor relates to the translation theories of Schleiermacher, Herder, and Benjamin (but, of course, also to the theories of Bakhtin and Derrida). Is the "old familiar bush" possibly understandable as a functional analogy for the "self-grown tree-trunk" of Herder upon which one has grafted all sorts of "foreign twigs"?

If this were the case, what would the poem of Yoko Tawada, which appeared in her book Abenteuer der deutschen Grammatik, [Adventures of German Grammar] mean?

Die 逃走 des 月s

我歌 auf der 厠

da 来 der 月 herange転

裸

auf einem 自転車

彼 hatte den道 mitten 通 den 暗喻公園 ge選

um 我 zu 会

戸外 die 道 entlang

散歩e 歯磨end eine 美女

auf der 長椅子 im 公園

飲 ein 男 in 妊婦服林榀汁

Am 末 eines 世紀s ist die 健康 eben 適

Im 天穿 ein 穴

Die 月的不安 Der 月的苦悩 sind 去

全「的」飛翔活発

um das 穴 herum

Die 貱 des 深淵s 平

Auf der 光滑en 表面 der 苦絁

登場 die 詩人 auf 水靴 an

月我的 neben我

Fig. 3: "Die Flucht des Mondes" by Yoko Tawada from: Abenteuer der deutschen Grammatik, p.41. 
A poem which, as she writes in a comment, is the transcription of the translation of her poem "Flight of the Moon" - written according to the same method that is used when combining Japanese and Chinese ideograms and phonetic transcriptions.

In order to write Japanese, one must write the roots of the meanings with Chinese ideograms and everything else (hands and feet of words) with a phonetic script. The poem shows that one can also write German with this mixing method.

(Tawada 2000, 41)

Here, the foreign colonies are no longer foreign words typeset in Antiqua that stand out against the Fraktur of 'native words.' The foreign colonies are now Chinese ideograms that are combined with German phonetic transcriptions according to the Japanese method of mobilizing foreign typographical characters. This is a conceptual and bodily form of the transplantation of characters that aims to bring them into an adventurous grammatical situation of a 'graftedscript-culture-contact,' and at the same time gives birth to a model of cultural translation adapting and inserting the elements of a foreign language as a 'graft.'

\section{References}

Acheraïou, Amar. Rethinking Postcolonialism: Colonialist Discourse in Modern Literatures and the Legacy of Classical Writers. New York: Palgrave Macmillan, 2008.

Allen, Oliver. Pruning and Grafting: The Time-Life Encyclopedia of Gardening. New York: Holt, 1978.

Austin, John L. How to Do Things with Words. Oxford: Oxford University Press, 1975 [1962].

Bachmann-Medick, Doris. Cultural Turns. Neuorientierungen in den Kulturwissenschaften. Reinbek: Rowohlt, 2006.

Bakhtin, Mikhail. The Dialogic Imagination: Four Essays. Ed. Michael Holquist. Austin: University of Texas Press, 2002.

Benjamin, Walter. "Die Aufgabe des Übersetzers." Gesammelte Schriften IV.1. (Kleine Prosa, Baudelaire Übertragungen). Ed. Tillman Rexroth. Frankfurt a.M.: Suhrkamp, 1991 [1921]. 9-21.

Benjamin, Walter. “The Task of the Translator.” Illuminations. Ed. Hannah Arendt. Trans. Harry Zohn. New York: Schocken, 2007 [1921]. 69-82.

Ben-Sasson, Haim, et al. "Assimilation.” Encyclopedia Judaica. Ed. Fred Skolnik and Michael Berenbaum. Farmington Hill: Macmillan Reference USA, 2007. 605-613.

Bertilsson, Thora. "The Social as Trans-Genic: On Bio-Power and Its Implications for the Social." Acta Sociologica: The Knowledge Society 46.2 (2003): 118-131.

Bhabha, Homi. "The Third Space: Interview with Homi Bhabha." Identity: Community, Culture, Difference. Ed. Jonathan Rutherford. London: Lawrence \& Wishart, 1990. 207-221.

Bhabha, Homi. The Location of Culture. London/New York: Routledge, 1994.

Blumenberg, Hans. Paradigmen zu einer Metaphorologie. 3rd ed. Frankfurt a.M.: Suhrkamp, 2005 [1960]. 
Böhme, Hartmut. "Vom Cultus zur Kultur(wissenschaft). Zur historischen Semantik des Kulturbegriffs." Literaturwissenschaft - Kulturwissenschaft: Positionen, Themen, Perspektiven. Eds. Renate Glaser and Matthias Luserke. Opladen: Westdeutscher Verlag, 1999. 48-68.

Bohnenkamp, Anne. "Hybrid statt verfremdend? Überlegungen zu einem Topos der Übersetzungstheorie.” Linguistische Aspekte der Übersetzungswissenschaft. Eds. Peter Colliander, Doris Hansen, and Ingeborg Zint-Dyhr. Tübingen: Julius Groos, 2004. 9-26.

Burke, Peter. What is Cultural History? Cambridge: Polity, 2004.

Culler, Jonathan. On Deconstruction: Theory and Criticism After Structuralism. Ithaca: Cornell University Press, 2007 [1982].

D’Alembert, Jean Le Rond, and Denis Diderot, eds. Lemma “Greffe." Encyclopédie. Vol. 7. Paris: Briasson, 1757. 921-924.

Darwin, Charles. The Variation of Animals and Plants Under Domestication. London: John Murray, 1868.

Derrida, Jacques. “Signature Event Context.” Limited Inc. Evanston, IL: Northwestern University Press, 1988 [1972]. 1-23.

Foucault, Michel. The Foucault Reader. Ed. Paul Rabinow. New York: Pantheon Books, 1984.

Foucault, Michel. Naissance de la Biopolitique: Cours au Collège de France. 1978-1979. Paris: Seuil, 2004.

García Canclini, Néstor. Hybrid Cultures: Strategies for Entering and Leaving Modernity. Minneapolis/London: University of Minnesota Press, 2005.

Giuriato, Davide. “'Blendlinge.' Zur Theorie der Übersetzung bei Friedrich Schleiermacher.” Impfen, Pfropfen, Transplantieren. Ed. Uwe Wirth. Berlin: Kadmos, 2011. 121-134.

Grimm, Jacob, and Wilhelm Grimm. Deutsches Wörterbuch. Leipzig: S. Hirzel, 1854-1971.

Hamilton, David, Clyde Barker, and Thomas Starzl, eds. A History of Organ Transplantation: Ancient Legends to Modern Practice. Pittsburgh: University of Pittsburgh Press, 2012.

Haraway, Donna. "A Cyborg Manifesto: Science, Technology, and Socialist-Feminism in the Late Twentieth Century." Simians, Cyborgs, and Women: The Reinvention of Nature. Ed. Donna Haraway. New York: Routledge, 1991 [1985]. 149-181.

Heidegger, Martin. “Die Frage nach der Technik.” Vorträge und Aufsätze. Ed. Martin Heidegger. Tübingen: Neske, 1967 [1953]. 5-36.

Herder, Johann Gottfried. “Über die neuere deutsche Literatur. Fragmente. Erste Sammlung. Zweite völlig umgearbeitete Ausgabe.” Werke in zehn Bänden. Vol. 1 (Frühe Schriften 1764-1772).

Ed. Ulrich Gaier. Frankfurt a.M.: Deutscher Klassiker Verlag, 1985 [1768]. 541-650.

Hertwig, Oskar. Allgemeine Biologie. Jena: Gustav Fischer, 1923 [1906].

Latour, Bruno: "Visualisation and Cognition: Drawing Things Together." Knowledge and Society: Studies in the Sociology of Culture Past and Present. Ed. Henrika Kuklick. Oxford: JAI Press, 1986. 1-40.

Latour, Bruno. We Have Never Been Modern. Ed. and transl. Cathrine Porter. Cambridge, MA: Harvard University Press, 1993.

Mudge, Ken, Jules Janick, Steven Scofield, and Eliezer E. Goldschmidt. "A History of Grafting.” Horticultural Reviews 35 (2009): 437-493.

Paré, Ambroise. CEuvres Complètes d'Ambroise Paré. III. Paris: Baillière, 1841 [1573].

Park, Robert E. "Human Migration and the Marginal Man." American Journal of Sociology 33.6 (1928): 881-893.

Paul, Jean. Leben Fibels. Werke in zwölf Bänden. Vol. 11. Ed. Norbert Miller, Munich: Hanser, 1975. 
Pratt, Mary Louise. Imperial Eyes: Travel Writing and Transculturation. 2nd ed.

London: Routledge, 2003.

Quine, Willard Van Orman. Word and Object. Cambridge, MA: MIT Press, 1960.

Rushdie, Salman. The Satanic Verses. New York: Penguin, 1988.

Schleiermacher, Friedrich. "Über die verschiedenen Methoden des Übersetzens.” Das Problem des Übersetzens. Ed. Hans Joachim Störig. Darmstadt: Wissenschaftliche Buchgesellschaft, 1973 [1813]. 38-69.

Schleiermacher, Friedrich. Hermeneutik und Kritik. Frankfurt a.M.: Suhrkamp, 1977 [1833].

Serres, Michel. Der Parasit. Frankfurt a.M.: Suhrkamp, 2008.

Shaftesbury, Anthony. Characteristicks of Men, Manners, Opinions, Times. Treatise VI. London: Printed by John Darby, 1711.

Sharrock, Robert. The History of the Propagation \& Improvement of Vegetables by the Concurrence of Art and Nature. Oxford: Lichfield 1659.

Siegert, Bernhard. "Kulturtechnik." Einführung in die Kulturwissenschaft. Eds. Harun Maye and Leander Scholz. Munich: Fink, 2011. 95-118.

Tawada, Yoko. Abenteuer der deutschen Grammatik. Tübingen: Konkursbuchverlag, 2000.

Weber, Max. "Die Wirtschaftsethik der Weltreligionen.” Gesammelte Aufsätze zur Religionssoziologie. Ed. Max Weber. Tübingen: Mohr, 1986 [1920]. 238-442.

Weber, Max. “Der Sozialismus.” Gesammelte Aufsätze zur Soziologie und Sozialpolitik. Ed. Max Weber. Tübingen: Mohr, 1988 [1918]. 492-517.

Wehde, Susanne. Typographische Kultur. Eine zeichentheoretische Studie zur Typographie und ihrer Entwicklung. Tübingen: Niemeyer, 2000.

Wirth, Uwe. "Gepfropfte Theorie. Eine 'greffologische' Kritik von Hybriditätskonzepten als Beschreibung von intermedialen und interkulturellen Beziehungen.” TheorieTheorie. Wider die Methodenmüdigkeit in den Geisteswissenschaften. Eds. Mario Grizelj and Oliver Jahraus. Paderborn: Fink, 2011a. 151-166.

Wirth, Uwe. "Kultur als Pfropfung. Pfropfung als Kulturmodell. Prolegomena zu einer Allgemeinen Greffologie (2.0).” Impfen, Pfropfen, Transplantieren. Ed. Uwe Wirth. Berlin: Kadmos, 2011b. 9-27.

Wirth, Uwe. "Between Hybrid and Graft." From Literature to Cultural Literacy. Eds. Naomi Segal and Daniela Koleva. London: Palgrave Macmillan, 2014. 232-249.

Wirth, Uwe. "Pfropfung als Kulturkontakt." Kulturkontakte. Szenen und Modelle in deutsch-japanischen Kontexten. Eds. Yuichi Kimura and Thomas Pekar. Bielefeld: transcript 2015. 29-48.

Wirth, Uwe. "Poetisches Paperwork. Pfropfung und Collage im Spannungsfeld von Cut and Paste." Paperworks. Literarische und kulturelle Praktiken mit Schere, Leim, Papier. Eds. Magnus Wieland and Irmgard Wirtz. Göttingen: Wallstein, 2017. 7-29.

Young, Edward. Conjectures on Original Composition. London: A. Millar; R. \& J. Dodsley, 1759.

Young, Robert J. C. Colonial Desire: Hybridity in Theory, Culture and Race. London/New York: Routledge, 1995.

Zedler, Johann Heinrich, ed. Großes vollständiges Universal-Lexikon aller Wissenschaften und Künste, welche bißhero durch menschlichen Verstand und Witz erfunden und verbessert worden. Vol. 3. Graz: Akad. Dr.- u. Verl.-Anst., 1961 [1753]. 